\title{
"ŠTO JE TO JEDAN METAR?" \\ REZULTATI KOMPARATIVNE ANALIZE REZULTATA TESTIRANJA DVA PRISTUPA UČENJA OVE TEME U VRTIĆU
}

\author{
Slavoljub Hilčenko ${ }^{1}$, Vukan Popović ${ }^{2}$ \\ Visoka škola strukovnih studija za obrazovanje vaspitača i trenera, Subotica, Srbija \\ Osnovna škola "Isa Bajić", Kula, Srbija
}

\section{Sažetak}

Studenti smjera za odgajatelje na Strukovnoj školi u Subotici iz nastavnog predmeta Primjena računala u vrtiću u okviru svojih vježbi razvijaju e-didaktička učila, koja nalaze svoju praktičnu primjenu u predškolskim odgojno-obrazovnim ustanovama na teritoriju Općina Subotice, Sombora, Vrbasa i Kule. Ovakva učila su vrlo oskudna, dok su ona dostupna ili na stranom jeziku ili ne zadovaljavaju didaktičko-metodičke aspekte. Sa druge strane, prema priznanju odgojitelja, oni zaziru od takvog pristupa radu, ukoliko nije jednostavan i intuitivan u primjeni, učinkovitiji i podsticajniji djeci od tradicionalnog pristupa. Cilj rada jeste predstavljanje jednog e-učila, odnosno komparativne analize rezultata testiranja oba pristupa na istu temu. Ostvareni eksperimentalni rezultati su na strani grupe djece predškolaca iz Metodike matematike, koja je koristila e-učilo - multimedijalno-animiranu i interaktivnu PowerPoint prezentaciju "Što je to jedan metar?" na tablet računalima u odnosu na tradicionalan pristup - aktivnost odgojitelja i provjeru znanja - klasičnim (neverbalno, tekstualno-aplikativnim) testom - radnim listom s 5 zadataka. Prije samog istraživanja, od svih ispitanika (400), verbalnom provjerom, 368 (92,0\%) djece je izrazilo stav da bi novu temu usvajali posredstvom e-učila, što potvrđuje stupanj motiviranosti koje ono implicitno/eksplicitno posjeduje.

Ključne riječi

E-učila, veća učinkovitost, motivacija, metar, jednostavna primjena.

\section{UVOD: E-UČILO"ŠTO JE TO JEDAN ME- TAR?", JEDNOSTAVNO U KORIŠTENJU, UČINKOVITIJE U UČENJU}

Stav odgojitelja u predškolskim ustanovama (somborske, subotičke, vrbaške, kulske) općine je da je neophodno osuvremeniti odgojno-obrazovni rad primjenom IT ali da su im adekvatna i primjerena e-učila u najvećem broju NEdostupna ili NEprimjereno za rad. Sa druge strane, većina njih ne raspolaže dovoljnim tehničkim znanjima (čitaj: samopouzdanjem) za njihovu neposrednu primjenu na aktivnostima. Polazeći od ovih saznanja, studenti i profesori na Visokoj školi strukovnih studija za obrazovanje vaspitača iz Subotice iz nastavnog predmeta Primjena računala iz vrtića, angažirani su oko zadatka da odgojnoobrazovnoj praksi predškolskih ustanova u svojoj sredini, osiguraju primjerena e-učila, razvijajući ih u skladu s većinom didaktičko-metotičkih zahtjeva koja su naveli i odgajatelji:

- Da su primjerena uzrastu djece, njihovim razvojnim psiho-fizičkim (kognitivnim i konativna) karakteristikama.

- Da potiču funkcionalno-logičke kapacitete svih uzrasnih skupina djece /1/,/2/.

- Da su utemeljene kao problemski zadaci, a NE da potiču reproduktivno znanje.

- Da pored teorijskog znanja, nude i praktične manipulativno-motoričke upute.

- Da su jednostavna i intuitivna u primjeni za odgojitelje, učinkovitija i podsticajnija djeci od tradicionalnog pristupa rada*.

*Prema našoj pretpostavci, najveća prepreka većoj primeni e-učila na aktivnostima u vrtiću, predstavljao je "NEprijateljski" ustrojena e-učila (IT u celini), pred kojima su vaspitači osećali strah i odbijali da ih uvode $\mathrm{u}$ radne sobe, zazor da bi nešto moglo da pođe po zlu, da NE bi bili osra- 
moćeni, ismejani i sl. *Prema našoj pretpostavci, najveća prepreka većoj primjeni e-učila na aktivnostima u vrtiću, predstavljao je "neprijateljsko" ustrojena e-učila (IT u cjelini), pred kojima su odgajatelji osjećali strah i odbijali da ih uvode u radne sobe, zazor da bi nešto moglo poći po zlu, da NE bi bili osramoćeni, ismijani i sl. U tom smislu je najpogodniji PowerPoint, koji "samo" na kliktaj miša ili dodir zaslona (PC ili tableta), pokreće sve od novog slajda, do zvuka, animacije, odgovaranja na pitanja u testu itd. Na internetu se mogu naći sajtovi na kojima korisnici mogu glasati za aplikacije koje koriste u obrazovanju i na kojima se godišnje objavljuju rezultati glasovanja. Jedan od takvih stranica je stranica Centre for Learning and Performance Technologies (C4LPT) Na listi "Top 200"' alata za 2017. godinu, ('Top 200 Tools for Learning 2017", bez datuma) Microsoft PowerPoint se nalazi na trećem mjestu, odnosno najpoželjniji je alat u skupini alata za prezentacije /3/ (slika br. 1).

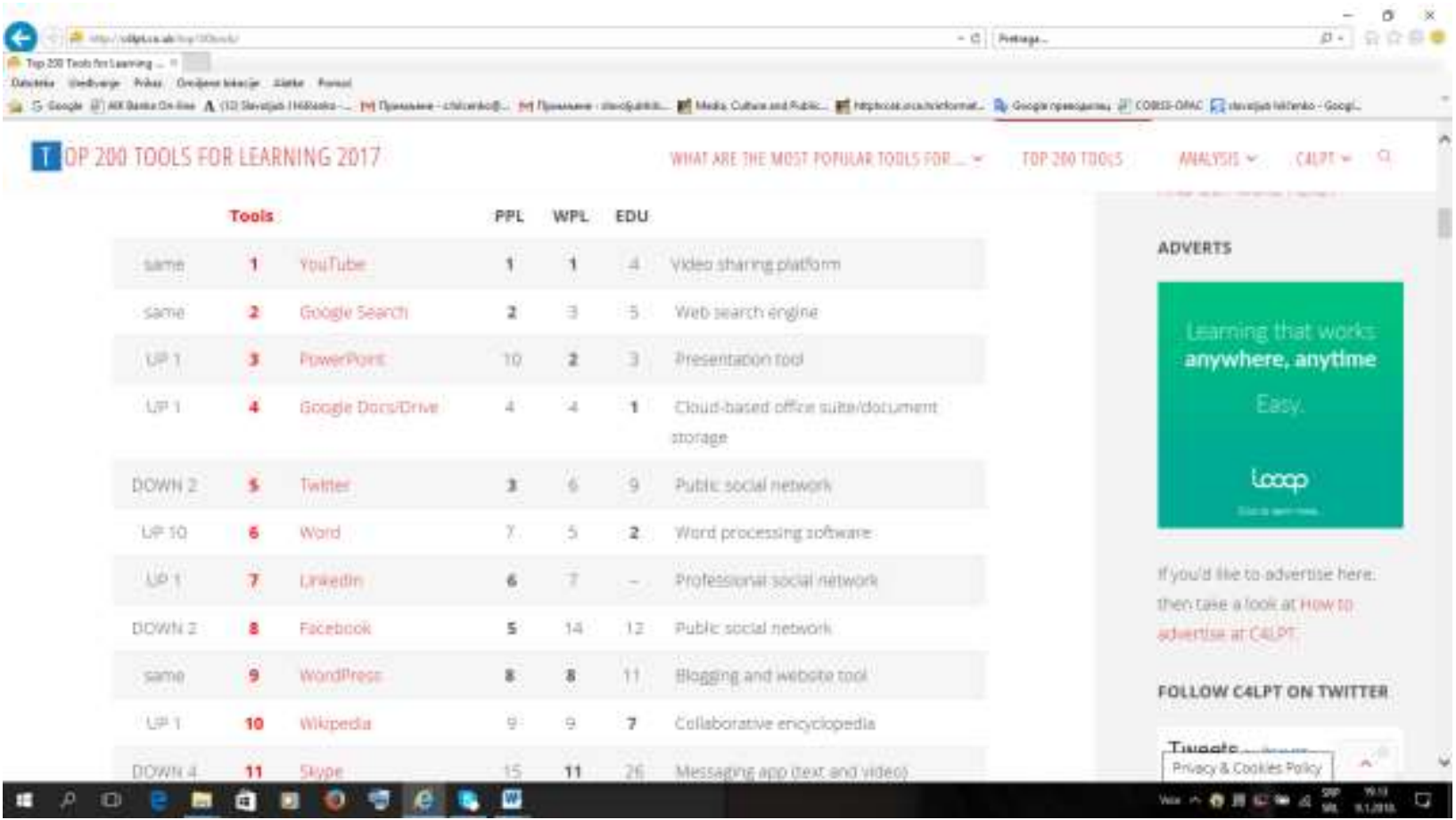

Slika br. 1: Primjeri e-učila koja se koriste u radu predškolskih ustanova diljem Vojvodine

Iz skupine razvijenih e-učila s temama: Mjerenje vremena; Brojimo od 1 do 10; Gore-dolje ... (slike br. 1a, 1b i 1c), kao primjer, izdvojili smo prezentaciju "Što je to jedan metar?", e-učilo od

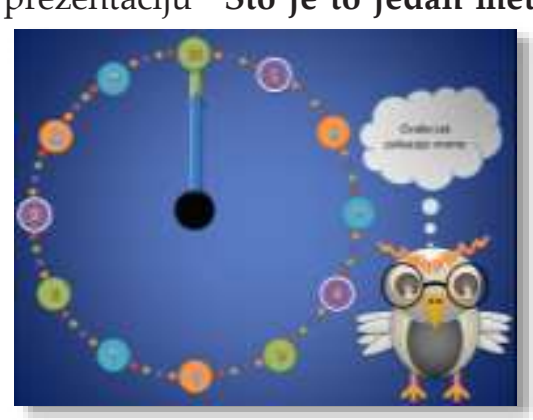

15 slajdova, kreirano je prema gore navedenim didaktičko-metodičkim zahtjevima (slike br. 3a i $3 b)$.

Slike br. 2a, 2b i 2c: Primjeri e-učila koja se koriste u radu predškolskih ustanova diljem Vojvodine 

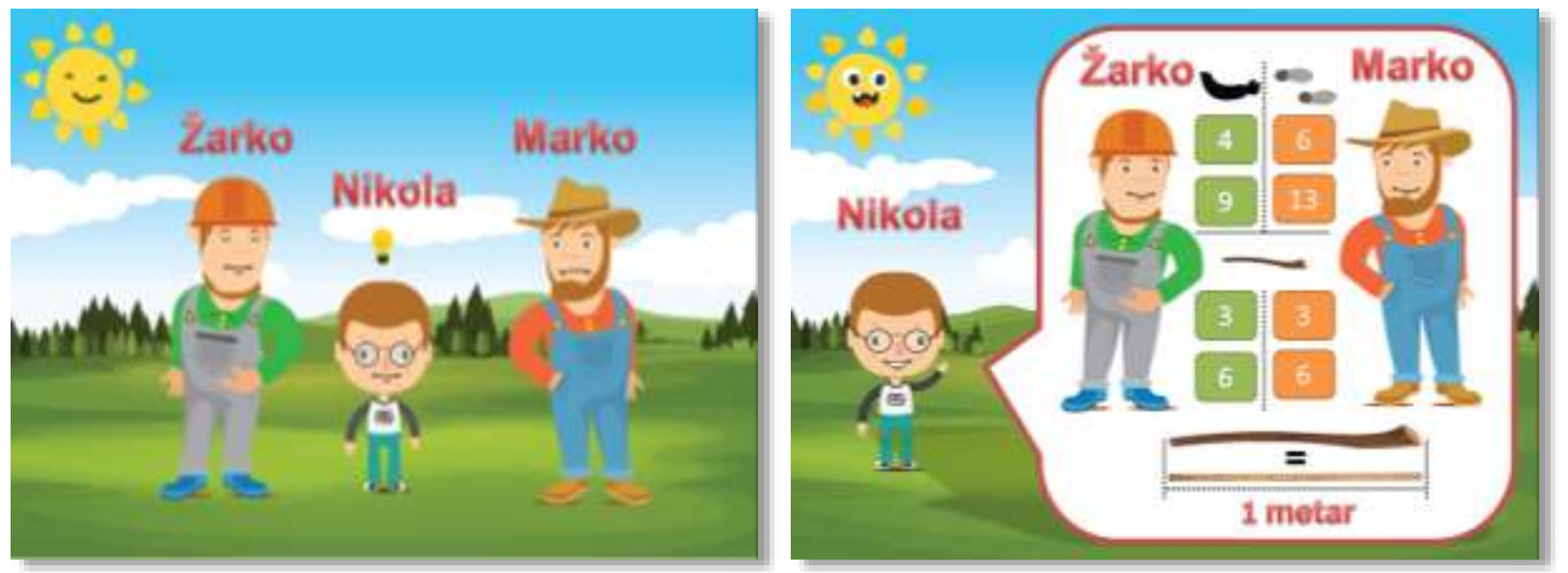

Slike br. 3a i 3b: E-učilo za obradu i provjeru znanja iz teme "Što je to jedan metar?"

U radu, Primjena multimedije $u$ oblasti podučavanja osnovnim matematičkim pojmovima $u$ predškolskoj ustanovi /4/, detaljno smo izložili uputstvo (za sve zainteresirane studente i odgajatelje) za kreiranje ove (i sličnih) prezentacija na Windowsovoj platformi i OpenOffice programu PowerPoint 2010 kao osnovnom programu. Pored toga, korišteni su i sljedeći programi: Adobe Illustrator CS5, Adobe Photoshop CS5, Microsoft Office Picture Manager, Voxal Voice Changer, online program za snimanje zvuka $/ 5 /$, online program za kreiranje GIF (animiranih slika) /6/, program za prebacivanje MR3 snimka u wav format kojeg podržava PowerPoint /7/, Snipping Tool.

Brojna istraživanjima, potvrđuju da djece u učenju posredstvom IKT (tablet i računalima), ostvaruju optimalnije rezultate na testovima, nego kada iste ispitivanja rješavaju u papirnatom obliku. Da u radu s ICT, djece predškolske dobi, pokazuju veću zainteresiranost, da podiže njihovu motivaciju za učenje i poboljšavaju koncentraciju za rad na različitim zadacima /8/, /9/, /10/, 11/.

Zadatke koje je trebalo ostvariti na aktivnosti u oba pristupa bili su sljedeći:

- Da putem tradicionalog pristupa, odnosno posredstvom animirane i interaktivne eprezentacije, djeca na zabavan i primjeren način upoznaju standardnu jedinicu za mjerenje duljine - metar, njegov značaj i način praktičnog mjerenja.

Uvodni dio (5 min.)

- Uz pomoć prigodnog didaktičkog materijala, odnosno, putem animiranih likova u e-učile, da djeca upoznaju s temom - METAR.

Glavni dio (10-15 min.)

- Djeca primjerenim tradicionalnim putem, odnosno prateći razgovor animiranih likova problemsku situaciju - pokušaj izmjere njivu (dužinom stopala i koraka - NEstandardne jedinice za mjerenje dužine). Problem mjerenja u e-učili, odgonetava mudar dječak s metarskim štapom čime svi saznaju da 1 METAR predstavlja mjeru za mjerenje duljine koja vrijedi u cijelom svijetu.

Završni dio (10-15 min.)

- Kvizom od 5 pitanja (s ponuđenim odgovorima u vidu slika, simbola), provjerava se teorijsko-praktična usvojenost / razumijevanje / primjena teme kod oba pristupa.

\section{METODOLOGIJA ISTRAŽIVANJA}

Problem eksperimentalnog istraživanja (s paralelnim skupinama) odnosio se na potvrdu ili odbacivanje polazne hipoteze, da će rezultati obrađene teme, Jedinica za mjerenje duljine metar, odnosno njenog završnog testa od 5 pitanja, primjenom e-učila, biti optimalniji u radu najstarije odgojne skupine predškolske djece (od 6 godina) $\mathrm{u}$ odnosu na tradicionalno testiranje njihovih vršnjaka. Iz ovoga proizlazi, da je predmet istraživanja bio, primjena e-učila (posredstvom tablet računala), odnosno njihov utjecaj na motiviranost djece na učinkovitost usvajanja znanja.

- Cilj istraživanja odnosio se na eksperimentalnu provjeru praktične primjene e-učila (IT) u podizanju kvalitete aktivnosti na jedan optimalniji razinu.

- Zadaci istraživanja išli su u dva smjera: a) komparaciju rezultata testiranja primjenom IT i tradicionalnog rada; b) utvrđivanje stupnja motivacije djece za jedan od predloženih oblika rada.

- Istraživačke hipoteze: OSNOVNA hipoteza da primjena e-učila u aktionosti ima statistički 
Slavoljub Hilčenko, Vukan Popović:"ŠTO JE TO JEDAN METAR?" REZULTATI KOMPARATIVNE ANALIZE REZULTATA TESTIRANJA DVA PRISTUPA UČENJA OVE TEME U VRTIĆU

značajniji utjecaj na podizanje rezultata testiranja djece predškolske dobi, nego kada se iste sadržine utvrđuju tradicionalnim testom na papiru. POMOĆNA hipoteza - da primjena IKT utječe na povećanje motivacije za rad.

Točnost postavljenih hipoteza provjerili smo na uzorku najstarije djece predškolske dobi (6 godina). Primijenjen je eksperimentalan metoda (s paralelnim skupinama) i metoda analize mjernog instrumenta (1. e-testa i 2. testa na listu papira sa po 5 pitanja i ponuđenim odgovorima u obliku crteža i simbola).

Tehnike i postupci istraživanja - broj raspoloživih / dostupnih tablet računala, spremnost ustanova i odgojitelja da organiziramo istraživanje, kao i ograničena sredstva, utjecali su i na broj uzorka. Istraživanje je provedeno u četiri grada Subotici, Somboru, Vrbasu i Kuli. U dvije ekviva- lentne i ujednačene grupe djece (po dobi i spolu 200 dječaka +200 djevojčica, zapravo 16 skupina od po 25-ro djece), realizirane su kompletne aktivnost na temu - Jedinica za mjerenje duljine - metar, od kojih je eksperimentalna radila primjenom e-učila (IKT), a kontrolna tradicionalnim putem. U završnom dijelu aktivnosti, djeca su rješavala identične testove (mjerni instrument) sa po 5 pitanja u skladu s modelom rada (1. interaktivno IKT, 2. na papiru, po principu zaokruživanja točnog odgovora). Završne testove su organizirale, pratile / nadzirale, prikupile i obradile rezultate same odgojiteljice.

\section{ANALIZA REZULTATA I KOMENTAR}

Pogledajmo analizu odgovora $\mathrm{u}$ testovima (zelenom bojom je označeno polje točnog odgovora):

Tablica br. 1: Odgovori na pitanje: "Čime Nikola može točno mjeriti dimenzije nekog predmeta?"

\begin{tabular}{|c|c|c|c|c|c|c|}
\hline & \multicolumn{6}{|c|}{$\begin{array}{c}\text { 1. Pitanje: } \\
\text { "Čime Nikola može točno mjeriti dimenzije nekog predmeta?" } \\
\text { ( Zaokruži pravu sliku!) }\end{array}$} \\
\hline & \multicolumn{3}{|c|}{ Odgovori - e-pristupa } & \multicolumn{3}{|c|}{ Odgovori - tradicionalnog pristupa } \\
\hline & štap & metar & \multirow{2}{*}{$\begin{array}{c}\text { korakom/ } \\
\text { laktom }\end{array}$} & štap & metar & \multirow{2}{*}{$\begin{array}{c}\text { Korakom } \\
\text { laktom }\end{array}$} \\
\hline & \multicolumn{2}{|c|}{ (slika br. 2b) } & & \multicolumn{2}{|c|}{ (slika br. $2 b)$} & \\
\hline Mean & 0,05 & 0,765 & 0,185 & 0,1 & 0,465 & 0,435 \\
\hline $\begin{array}{c}\text { Std. error of } \\
\text { Mean }\end{array}$ & 0,218491861 & 0,425062809 & 0,389271966 & 0,300752824 & 0,500025125 & 0,497001057 \\
\hline Median & 0 & 1 & 0 & 0 & 0 & 0 \\
\hline Mode & 0 & 1 & 0 & 0 & 0 & 0 \\
\hline Variance & 0,047738693 & 0,180678392 & 0,151532663 & 0,090452261 & 0,250025126 & 0,24701005 \\
\hline Skewness & 0,377917598 & 0,100502513 & 2,053122757 & 0,969845265 & 0,201764971 & 0,26421097 \\
\hline Kurtosis & $-1,86653615$ & $-1,999924054$ & 2,226420232 & $-1,064749038$ & $-1,969161892$ & $-1,94979197$ \\
\hline Range & 1 & 1 & 1 & 1 & 1 & 1 \\
\hline Minimum & 0 & 0 & 0 & 0 & 0 & 0 \\
\hline Maximum & 1 & 1 & 1 & 1 & 1 & 1 \\
\hline
\end{tabular}

Grafikon br. 1: Postotak danih odgovora na 1. pitanje testa.

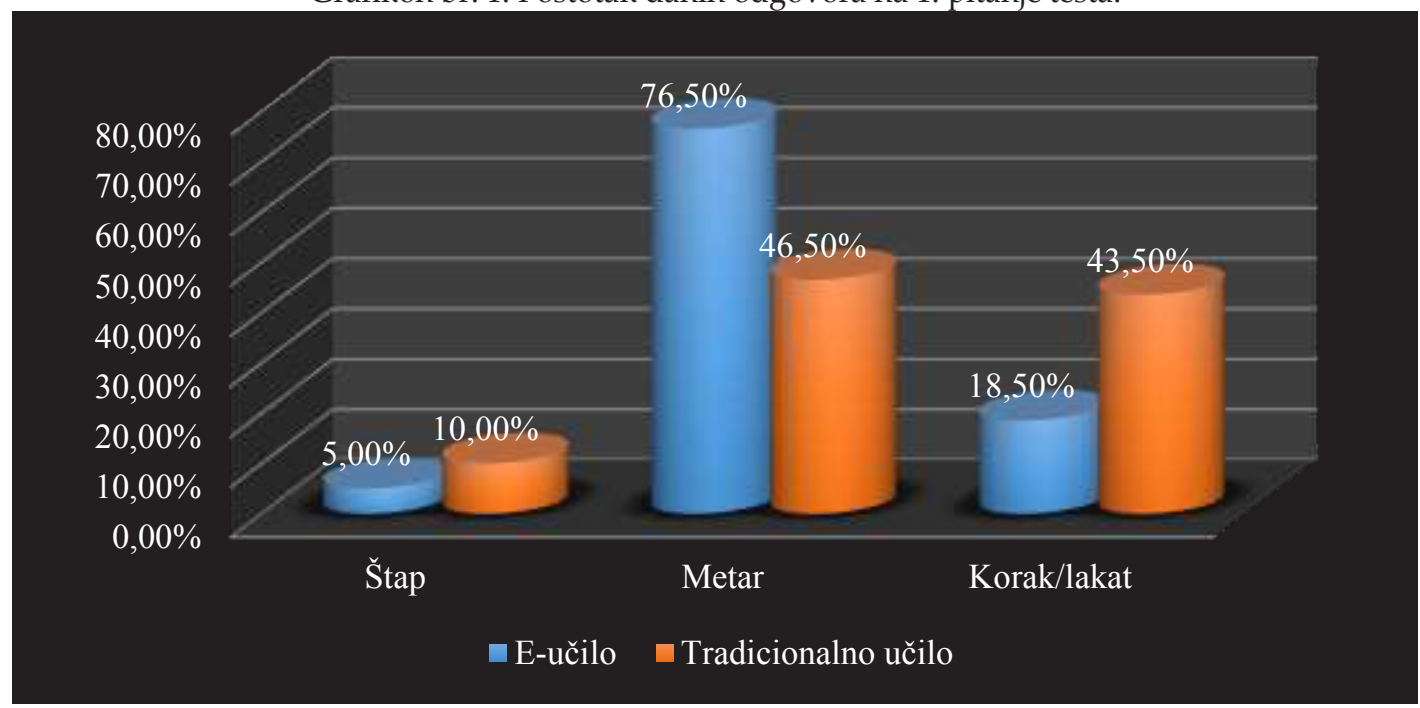


Slavoljub Hilčenko, Vukan Popović: "ŠTO JE TO JEDAN METAR?" REZULTATI KOMPARATIVNE ANALIZE REZULTATA TESTIRANJA DVA PRISTUPA UČENJA OVE TEME U VRTIĆU

Media, Culture and Public Relations, 9, 2018, 1-2, 69-80

Tabela br. 2: Odgovori na 1. pitanje testa, koje je imalo dva točna odgovora: metar i štap dug $1 \mathrm{~m}$.

\begin{tabular}{|c|c|c|c|}
\hline & štap & metar & korakom/laktom \\
\hline E-učilo (IKT) & 10 & 153 & 37 \\
\hline Tradicionalno učilo & 20 & 93 & 87 \\
\hline
\end{tabular}

Tabela br. 3: Vrednost t-testa pitanje 1.

\begin{tabular}{|c|c|c|c|}
\hline & Teorijska vrednost & Stepen slobode & Vrednost t-testa \\
\hline Pitanje 1. & 1,960 & 398 & 9,11955 \\
\hline
\end{tabular}

Tabela br. 3 prikazuje postojanje statistički značajne razlike između odgovora e-učila i tradicionalnog učila $\left(\mathrm{t}_{398}<\mathrm{t}_{398, \alpha}=1,960 ; \alpha=0,05\right)$.

Grafikon br. 2: Postotak točnih odgovora na 1. pitanje na testu, koje je imalo dva točna odgovora - metar i štap dug $1 \mathrm{~m}$.

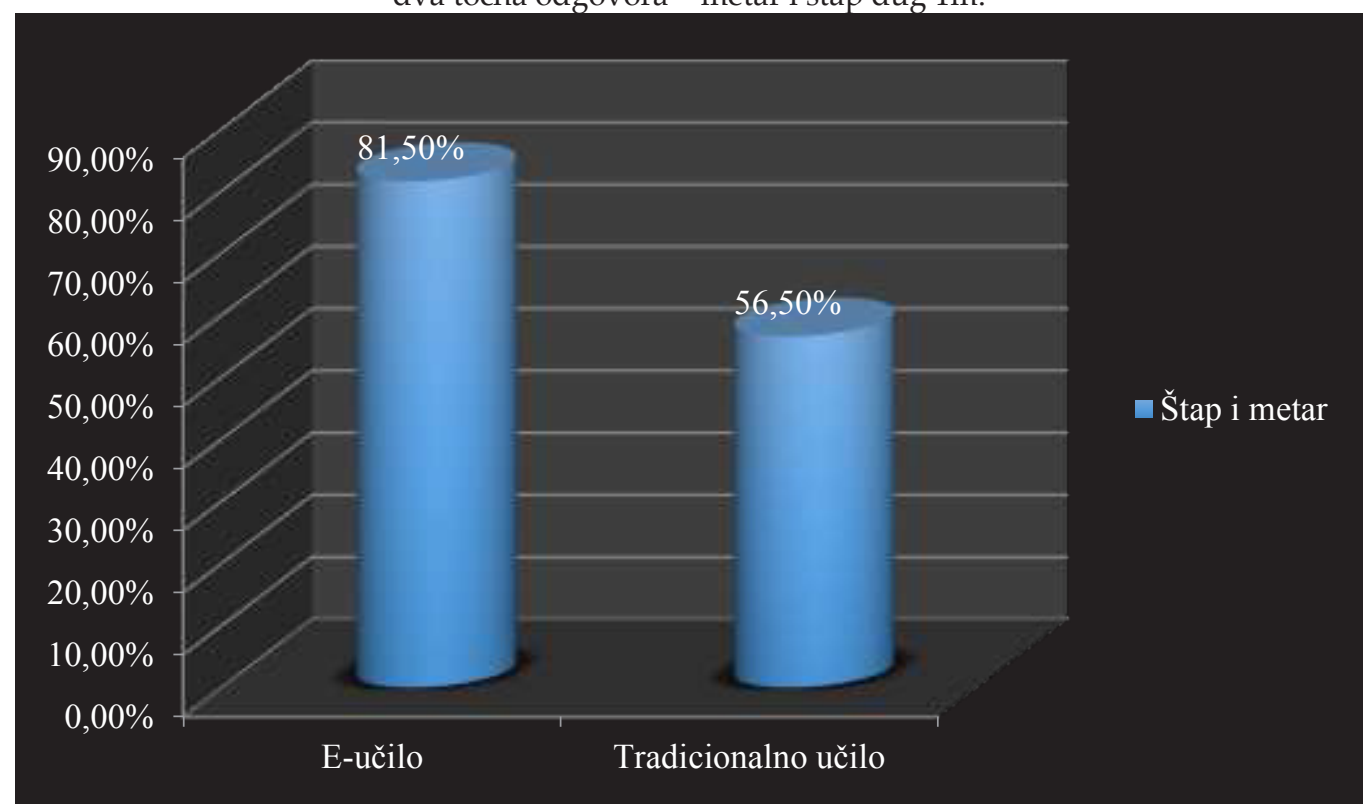

Tabela br. 4: 2. pitanje - deskriptivna statistika

\begin{tabular}{|c|c|c|c|c|}
\hline & \multicolumn{4}{|c|}{$\begin{array}{c}\text { 2. Pitanje: } \\
\text { "Koja je kraća jedinica za mjerenje od metra koja se spominje u priči?" } \\
\text { (Zaokruži pravu sliku!) }\end{array}$} \\
\hline & \multicolumn{2}{|c|}{ Odgovori - e-pristupa } & \multicolumn{2}{|c|}{ Odgovori - tradicionalnog pristupa } \\
\hline & korak & lakat & korak & lakat \\
\hline & \multicolumn{4}{|c|}{ (slika br. 2b) } \\
\hline Mean & 0,97 & 0,03 & 0,79 & 0,21 \\
\hline Std. error of Mean & 0,171015295 & 0,171015295 & 0,408330342 & 0,408330342 \\
\hline Median & 1 & 0 & 1 & 0 \\
\hline Mode & 1 & 0 & 1 & 0 \\
\hline Variance & 0,029246231 & 0,029246231 & 0,166733668 & 0,166733668 \\
\hline Skewness & $-5,552105436$ & 5,552105436 & $-1,434766231$ & 1,434766231 \\
\hline Kurtosis & 29,11695848 & 29,11695848 & 0,059044099 & 0,059044099 \\
\hline Range & 1 & 1 & 1 & 1 \\
\hline Minimum & 0 & 0 & 0 & 0 \\
\hline Maximum & 1 & 1 & 1 & 1 \\
\hline
\end{tabular}

Tabela br. 5: Odgovori na 2. pitanje

\begin{tabular}{|c|c|c|}
\hline & korak & lakat \\
\hline E-učilo (IKT) & 194 & 6 \\
\hline Tradicionalno učilo & 158 & 42 \\
\hline
\end{tabular}


Slavoljub Hilčenko, Vukan Popović:" ŠTO JE TO JEDAN METAR?" REZULTATI KOMPARATIVNE ANALIZE REZULTATA TESTIRANJA DVA PRISTUPA UČENJA OVE TEME U VRTIĆU

Media, Culture and Public Relations, 9, 2018, 1-2, 69-80

Tabela br. 6: Vrednost t-testa pitanje 2.

Pitanje 2. Teorijska vrednost 1,960 Stepen slobode 398 Vrednost t-testa 8,11163

Tabela br. 6 prikazuje postojanje statistički značajne razlike između odgovora e-učila i tradicional$\operatorname{nog}$ učila $\left(\mathrm{t}_{398}<\mathrm{t}_{398, \alpha}=1,960 ; \alpha=0,05\right)$.

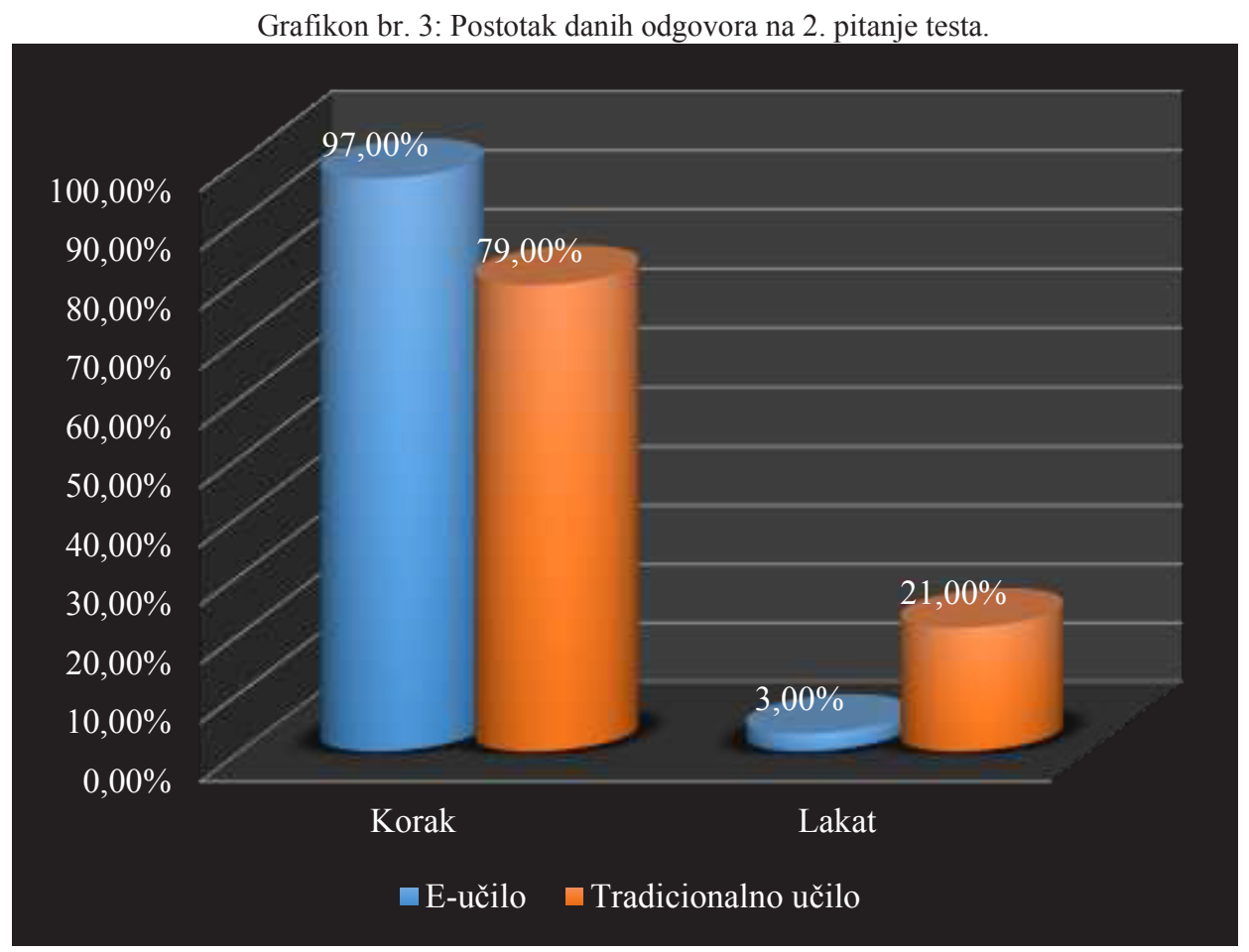

Tabela br. 7: 3. pitanje - deskriptivna statistika

\begin{tabular}{|c|c|c|c|c|c|c|}
\hline & \multicolumn{6}{|c|}{$\begin{array}{l}\text { 3. Pitanje: } \\
\text {,'Koja slika pokazuje pravilan postupak mjerenja duljine, ako je predmet duži od jednog metra?," } \\
\text { (Zaokruži pravu sliku!) }\end{array}$} \\
\hline & \multicolumn{3}{|c|}{ Odgovori - e-pristupa } & \multicolumn{3}{|c|}{ Odgovori - tradicionalnog pristupa } \\
\hline & broj 1 & broj 2 & broj 3 & broj 1 & broj 2 & broj 3 \\
\hline Mean & 0 & 0,985 & 0,015 & 0,045 & 0,405 & 0,55 \\
\hline Std. error of Mean & 0 & 0,12185748 & 0,12185748 & 0,20782434 & 0,4921239 & 0,49874214 \\
\hline Median & 0 & 1 & 0 & 0 & 0 & 1 \\
\hline Mode & 0 & 1 & 0 & 0 & 0 & 1 \\
\hline Variance & 0 & 0,01484925 & 0,01484925 & 0,04319095 & 0,24218593 & 0,24874372 \\
\hline Skewness & 0,03011643 & 0 & 5,53114101 & 1,32206848 & 0,09043073 & $-0,2025297$ \\
\hline Kurtosis & $-2,009164$ & $-2,0100756$ & 28,7371835 & $-0,2534272$ & $-2,0018568$ & $-1,9788719$ \\
\hline Range & 0 & 1 & 1 & 1 & 1 & 1 \\
\hline Minimum & 0 & 0 & 0 & 0 & 0 & 0 \\
\hline Maximum & 0 & 1 & 1 & 1 & 1 & 1 \\
\hline
\end{tabular}

Tabela br. 8: Odgovori na 3. pitanje

\begin{tabular}{|c|c|c|c|}
\hline & slika broj 1 & slika broj 2* & slika broj 3 \\
\hline E-učilo (IKT) & 0 & 197 & 3 \\
\hline Tradicionalno učilo & 9 & 81 & 110 \\
\hline
\end{tabular}

Tabela br. 9: Vrednost t-testa pitanje 3.

\begin{tabular}{|c|c|c|c|}
\hline & Teorijska vrednost & Stepen slobode & Vrednost t-testa \\
\hline Pitanje 3. & 1,960 & 398 & 22,82303 \\
\hline
\end{tabular}

Tabela br. 9 prikazuje postojanje statistički značajne razlike između odgovora e-učila i tradicionalnog učila $\left(\mathrm{t}_{398}<\mathrm{t}_{398, \alpha}\right.$ $=1,960 ; \alpha=0,05)$. 


\section{PITANJE EPOJ 3}

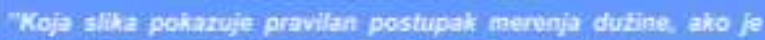

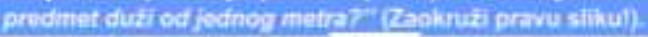

1.

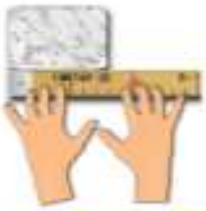

2.

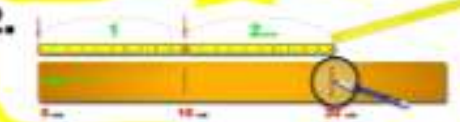

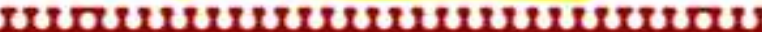

PITANJE EPOJ 3

"Koja silka pokazuje provilan postupak morenja dotime, ako je predmet duzi od jednog metra?" (Zaohruzi pravu silkmi)

1.

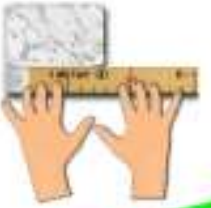

2.

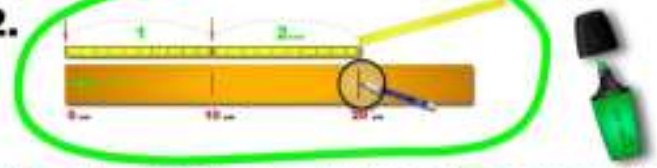

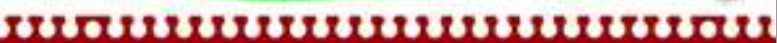

* Slika br. 3: Slika broj 2 predstavlja točan odgovor e-testom i na papiru.

Grafikon br. 4: Postotak danih odgovora na 3. pitanje testa.

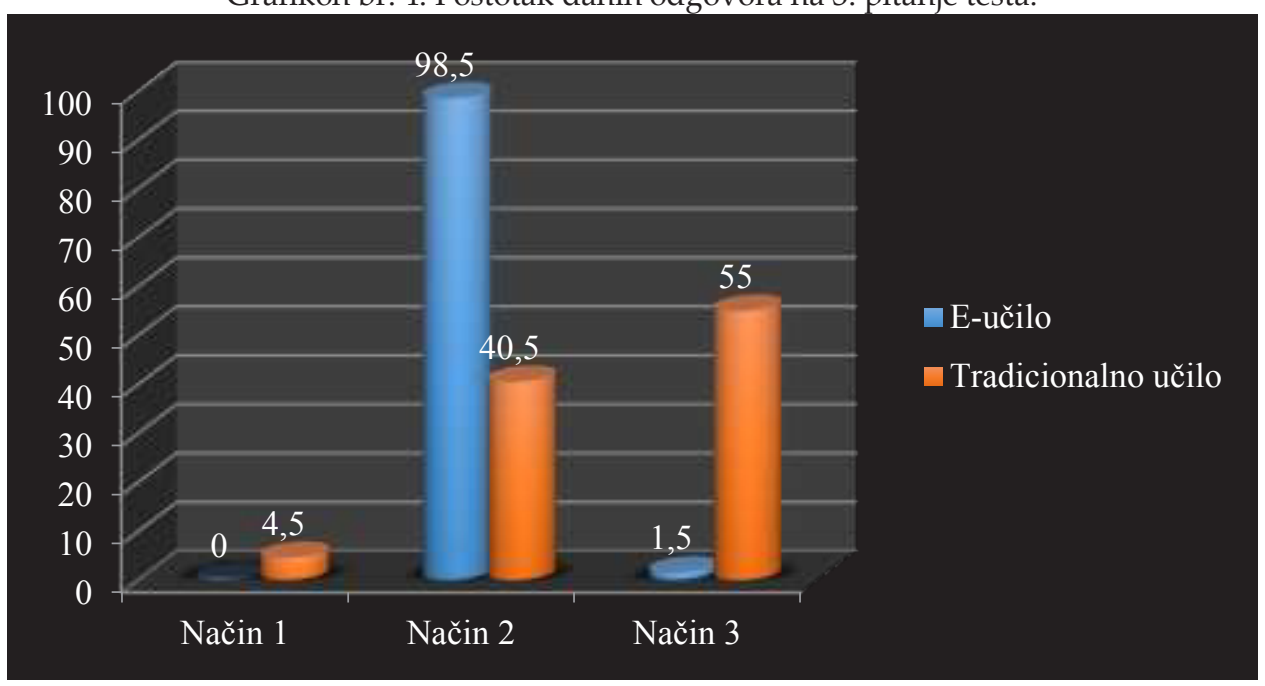

Tabela br. 10: 4. pitanje - deskriptivna statistika

\begin{tabular}{|c|c|c|c|c|c|c|}
\hline & \multicolumn{6}{|c|}{$\begin{array}{l}\text { 4. Pitanje: } \\
\text { ice su dužine } 5 \text { m, a duže stranice su još za toliko duže. Kolika } \\
\text { ıa dulje stranice njive?" } \\
\text { (ruži pravi odgovor!) }\end{array}$} \\
\hline & \multicolumn{3}{|c|}{ Odgovori - e-pristupa } & \multicolumn{3}{|c|}{ Odgovori - tradicionalnog pristupa } \\
\hline & $5 \mathrm{~m}$ & $10 \mathrm{~m}$ & $20 \mathrm{~m}$ & $5 \mathrm{~m}$ & $10 \mathrm{~m}$ & $20 \mathrm{~m}$ \\
\hline Mean & 0,02 & 0,94 & 0,04 & 0,09 & 0,79 & 0,12 \\
\hline $\begin{array}{l}\text { Std. error of } \\
\text { Mean }\end{array}$ & 0,14035132 & 0,23808279 & 0,19645092 & 0,28689991 & 0,40833034 & 0,325777 \\
\hline Median & 0 & 1 & 0 & 0 & 1 & 0 \\
\hline Mode & 0 & 1 & 0 & 0 & 1 & 0 \\
\hline Variance & 0,01969849 & 0,05668342 & 0,03859296 & 0,08231156 & 0,16673367 & 0,10613065 \\
\hline Skewness & 0,08036576 & 0,04015875 & 3,54233916 & 0,24265781 & 0,18141447 & 2,35644864 \\
\hline Kurtosis & $-2,0035845$ & $-2,0084547$ & 10,6011481 & $-1,9508969$ & $-1,976999$ & 3,58863788 \\
\hline Range & 1 & 1 & 1 & 1 & 1 & 1 \\
\hline Minimum & 0 & 0 & 0 & 0 & 0 & 0 \\
\hline Maximum & 1 & 1 & 1 & 1 & 1 & 1 \\
\hline
\end{tabular}

Tabela br. 11: Odgovori na 4. pitanje testa.

\begin{tabular}{|c|c|c|c|}
\hline & $5 \mathrm{~m}$ & $10 \mathrm{~m}$ & $20 \mathrm{~m}$ \\
\hline E-učilo (IKT) & 4 & 188 & 8 \\
\hline Tradicionalno učilo & 18 & 158 & 24 \\
\hline
\end{tabular}


Slavoljub Hilčenko, Vukan Popović:"ŠTO JE TO JEDAN METAR?" REZULTATI KOMPARATIVNE ANALIZE REZULTATA TESTIRANJA DVA PRISTUPA UČENJA OVE TEME U VRTIĆU

\begin{tabular}{|c|c|c|c|}
\hline \multicolumn{3}{|c|}{ Tabela br. 12: Vrednost t-testa pitanje 3. } \\
\hline & Teorijska vrednost & Stepen slobode & Vrednost t-testa \\
\hline Pitanje 4. & 1,960 & 398 & 6,33103 \\
\hline
\end{tabular}

Tabela br. 12 prikazuje postojanje statistički značajne razlike između odgovora e-učila i tradicionalnog učila $\left(\mathrm{t}_{398}<\mathrm{t}_{398, \alpha}=1,960 ; \alpha=0,05\right)$.

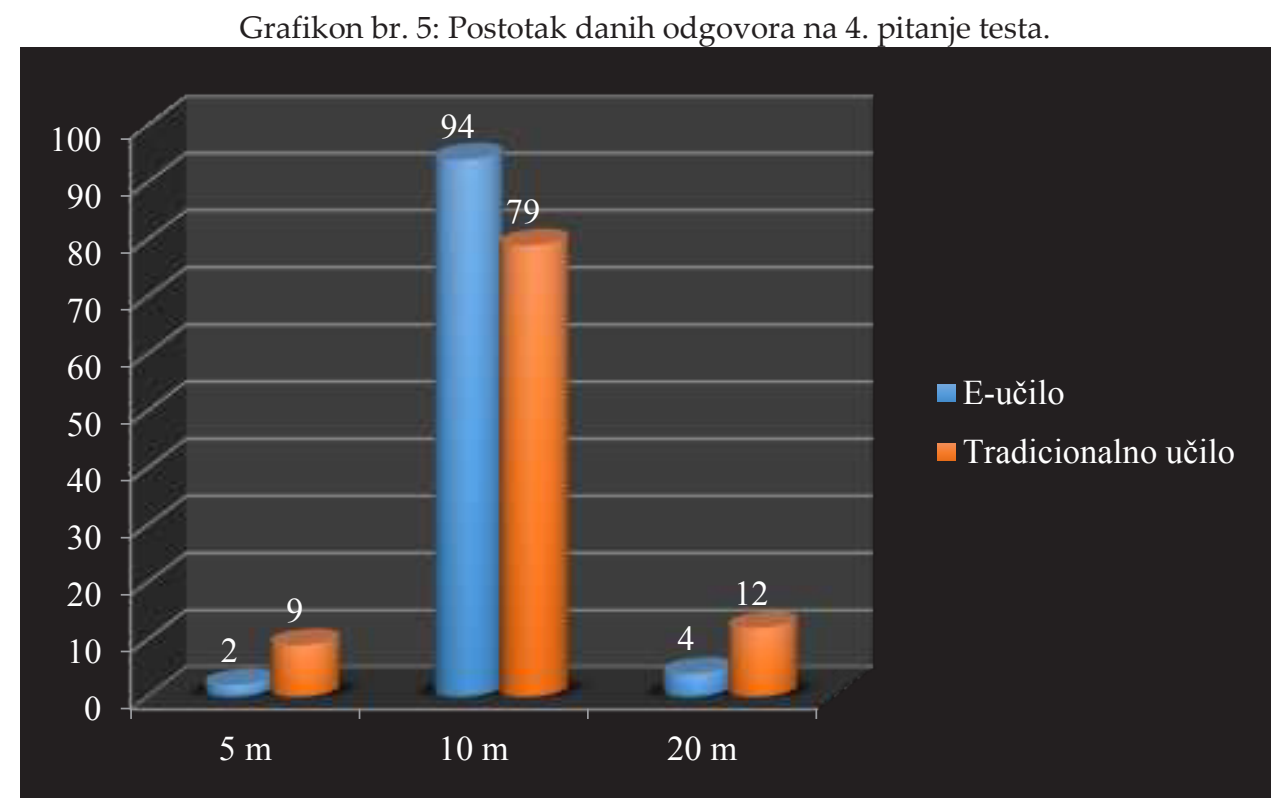

Tabela br. 13: 5. pitanje - descriptivna statistika

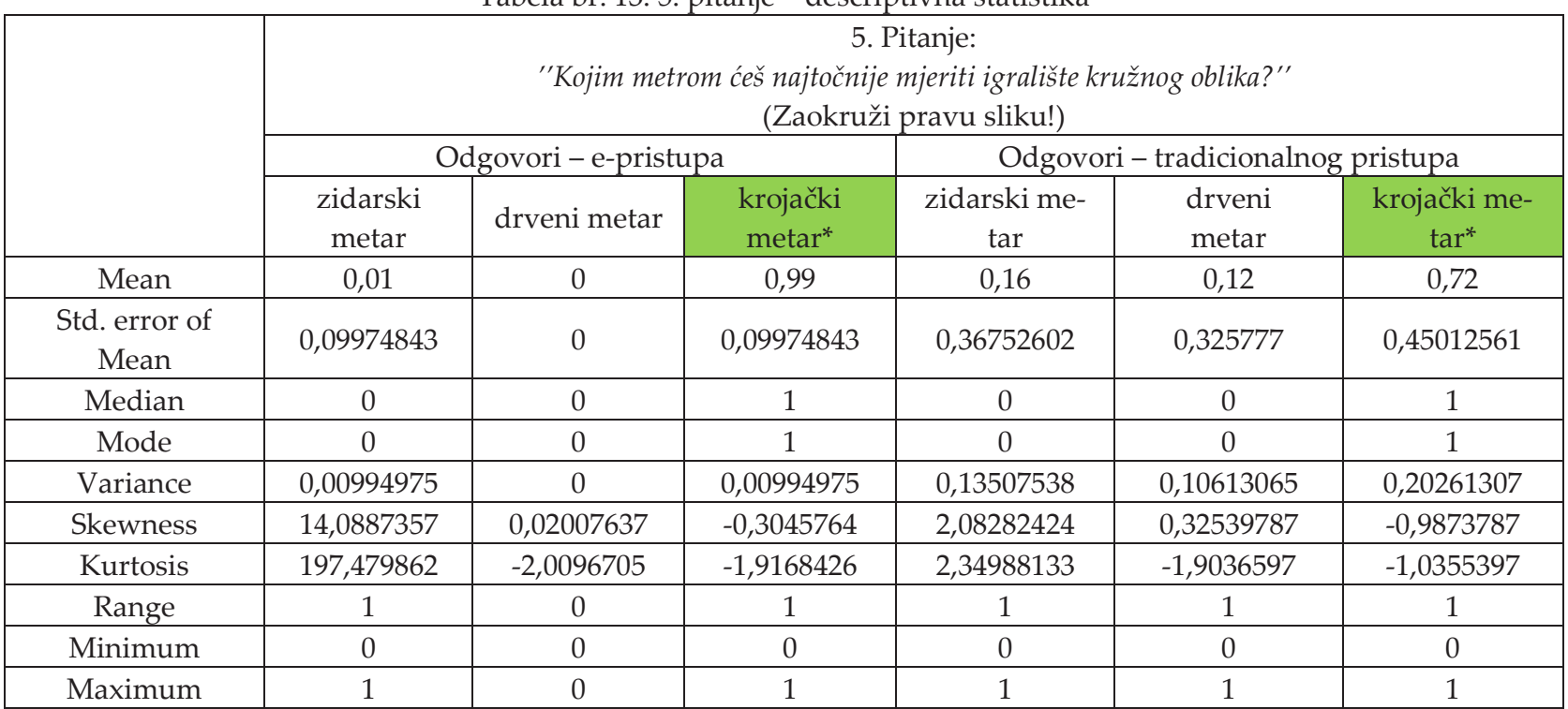

Tabela br. 14: Odgovori na 5. pitanje testa.

\begin{tabular}{|c|c|c|c|}
\hline & zidarski metar & drveni metar & krojački metar* $^{*}$ \\
\hline E-učilo (IKT) & 2 & 0 & 198 \\
\hline Tradicionalno & 32 & 24 & 144 \\
\hline
\end{tabular}

Tabela br. 15: Vrednost t-testa pitanje 3.

\begin{tabular}{|c|c|c|c|}
\hline & Teorijska vrednost & Stepen slobode & Vrednost t-testa \\
\hline Pitanje 4. & 1,960 & 398 & 11,68319 \\
\hline
\end{tabular}

Tabela br. 15 prikazuje postojanje statistički značajne razlike između odgovora e-učila i tradicionalnog učila ( $\mathrm{t} 398<\mathrm{t}$ $398, \alpha=1,960 ; \alpha=0,05)$. 


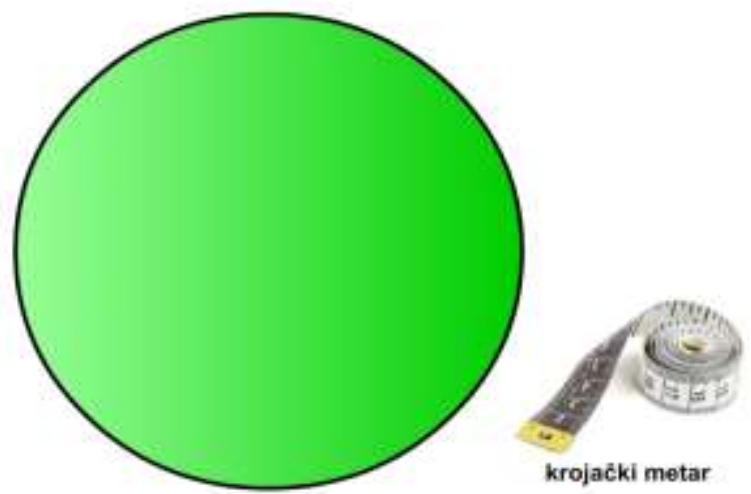

* Slika br. 4. Slika točnog odgovora je broj 3 - krojački metar.

Grafikon br. 6: Postotak točnih odgovora na 5. pitanje testa.

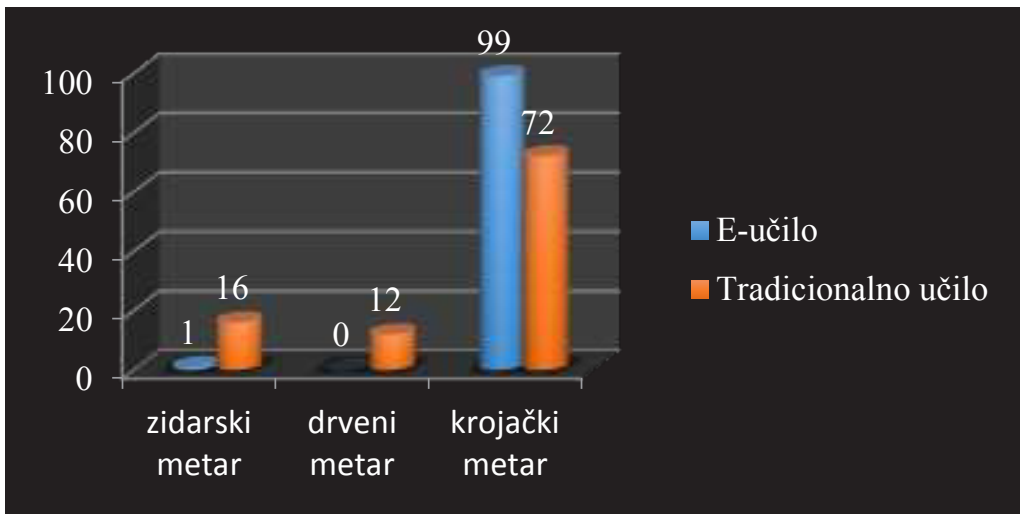

\section{KOMPARATIVNA ANALIZA REZULTATA}

Na grafikonu br. 7, predstavljeni su uporedni rezultati testa obje skupine.

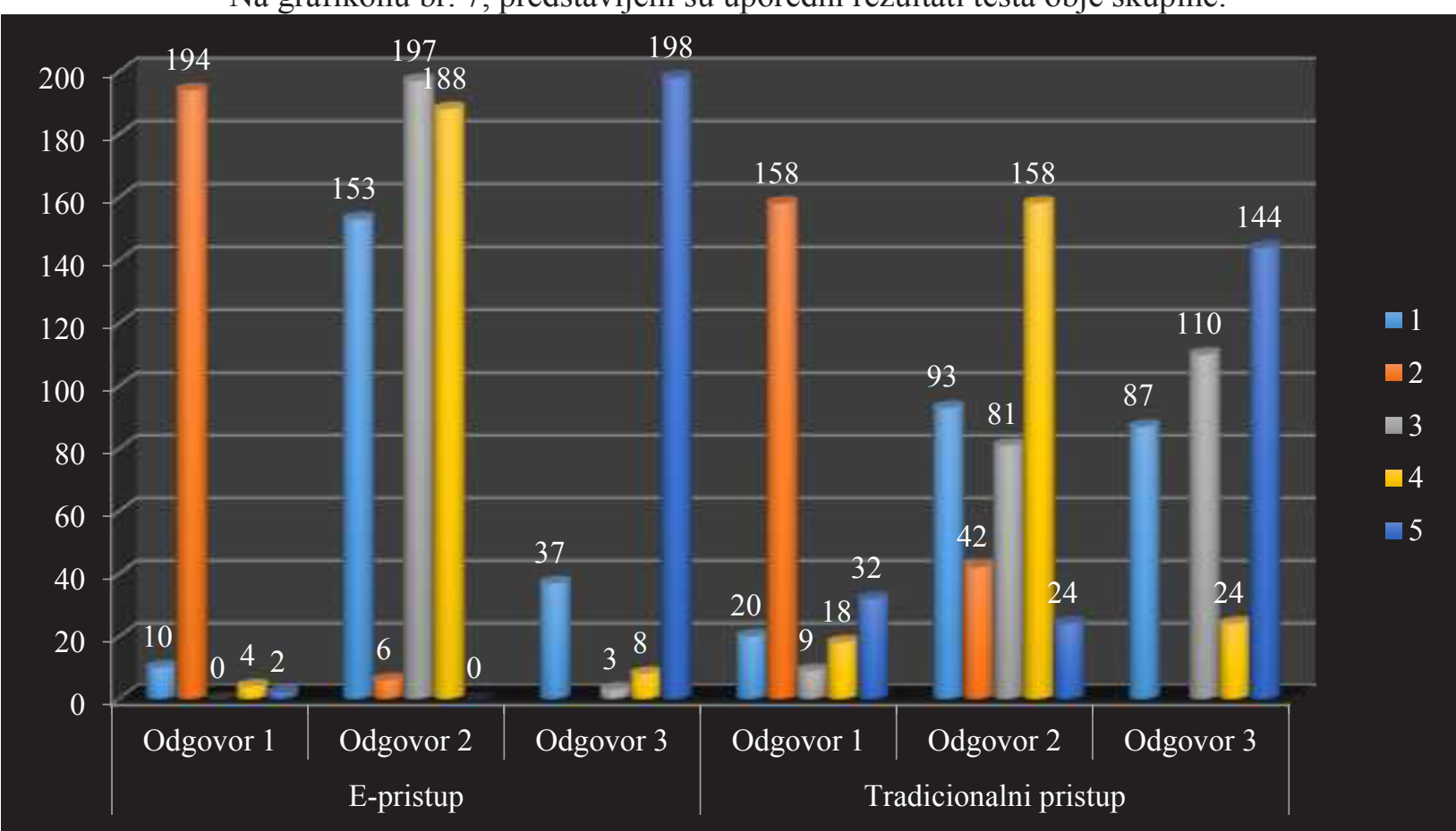

Uočava se da se bolji rezultati na svim testovima postižu pri radu s tabletom, tj. korištenjem e-učila. Statistički značajne razlike u postignuću dobivene su na svim postavljenim pitanjima. 
Slika 9. Ukupan broj točnih odgovora na testu e-pristupom (ICT) i tradicionalno.

\section{Točni odgovori po pitanjima}

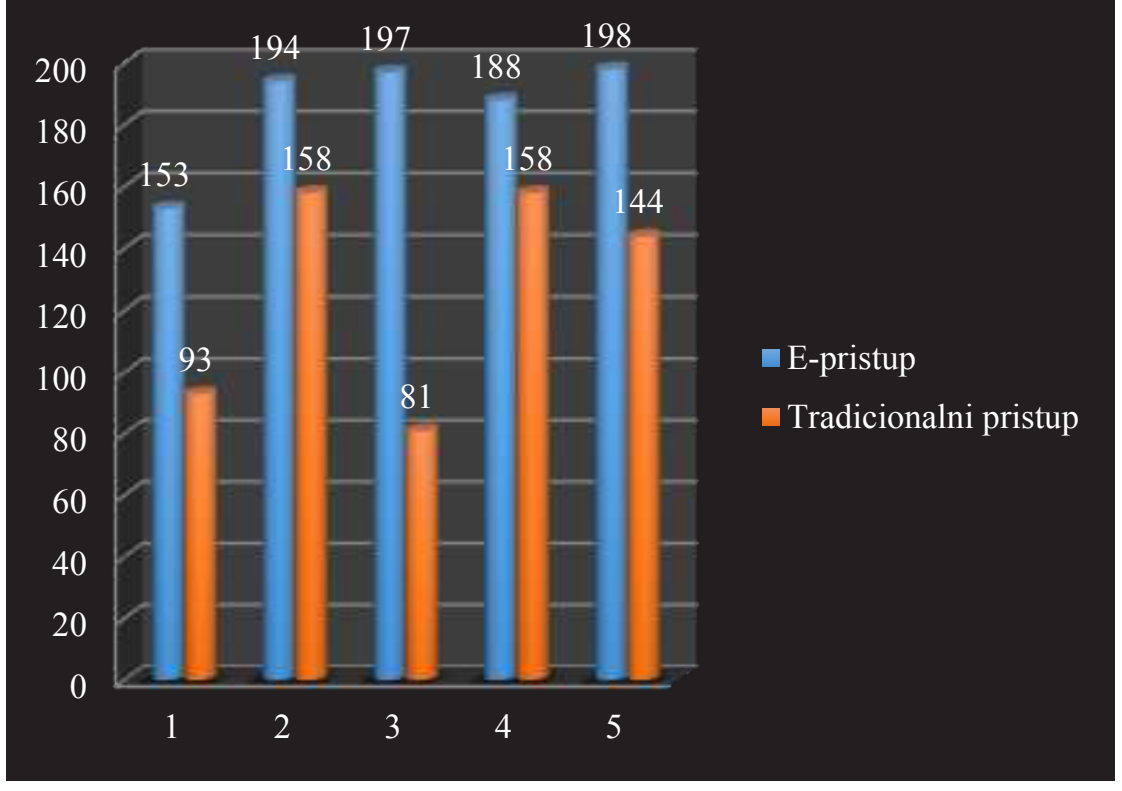

\section{ZAKLJUČAK}

Uvidom $\mathrm{u}$ zbirne rezultate na provedenim testovima od po 5 pitanja (e-učilo i tradicionalno) -možemo zaključimo, da su uporedni rezultati na strani e-pristupa (IKT) u odnosu na tradicionalno testiranje (papir + olovka). Ovo se odnosi kako na svako od pojedinačnih pitanja, tako i na ukupni test, što navodi da se naša OSNOVNA hipoteza potvrdila,

- Da primjena e-učila u aktionosti ima statistički značajniji utjecaj na podizanje rezultata testiranja djece predškolske dobi, nego kada se iste sadržine utvrđuju tradicionalnim testom na papiru.

\section{POMOĆNA hipoteza:}

- Da primjena IKT utječe na povećanje motivacije za rad, provjerena je samo usmenim putem $i$ to prije samog istraživanja, gdje je od 400 djece, njih 368 (ili 92,0\%), izrazilo želju da novu temu usvaja primjenom e-učila (IKT).

Na temelju rezultata provedenog istraživanja proizlaze sljedeći generalni zaključci:

Pri radu s tabletom, djeca su imala veći broj točnih odgovora na svim testovima, nego kada iste ispitivanja rješavaju $\mathrm{u}$ papirnatom obliku. Prikazani rezultati pomažu jasnijem razumijevanju definiranog problema. Slična istraživanja - testiranje putem interneta uz pomoć Tablet računala - pokazuje nesumljivo prednosti u odnosu na tradicionalni način testiranja pomoću testova papir + olovka. To podrazumijeva brzo i lako prikupljanje informacija i naročito olakšava statističku obradu /12/. Taktilni način komunikacije putem touch screena je najbliži prirodnom načinu na koji djeca ovog uzrasta istražuju i komuniciraju s okolinom, što je u skladu s pedagoškim principima (očiglednosti, individualizacije, prilagođenosti uzrastu...) i principima održivog razvoja $/ \mathbf{1 3} /$.

Ovaj rad predstavlja pilot istraživanje i proveden je na malom uzorku djece, jer je materijalni momenat u ovom slučaju bio limitirajući faktor. Kako postoji tendencija uvođenja tablet računala $\mathrm{u}$ predškolske ustanove, njihovom većom dostupnošću, buduća istraživanja bi trebali obuhvatiti veći uzorak ispitanika, kao i veći broj različitih testova, koji bi bili prezentirani putem ove tehnologije.

Na taj način budući eksperimenti bi se mogli provesti sa većim brojem djece različitih uzrasta. Pogotovo bi se mogli primijeniti na djeci mlađeg predškolskog uzrasta, jer kako rezultati eksperimenata iz razvijenih zemalja pokazuju, rad s tablet računalima je mlađoj djeci veoma interesantan, podiže njihovu motivaciju za učenje i poboljšava koncentraciju za rad, na različitim vrstama zadataka.

Buduća istraživanja trebalo bi obuhvatiti veći broj multimedijskih zadataka koji sadrže slike i riječi, odnosno uključivanje semantičnog sadržaja za djecu starijeg uzrasta, kao i auditivnu 
prezentaciju stimulusa. Također, kao pokazatelj poticajnog utjecaja tableta na usvajanje pojmova, pored točnosti odgovora, moglo bi se uvesti i mjerenje vremena reagiranja. U svakom slučaju, primjena tablet računala pospješuje angažiranje i kreativnost djece $i$ što je još važnije razvija različite sposobnosti, pripremajući ih za uspješno funkcioniranje $\mathrm{u}$ društvu budućnosti - društvu znanja, koje se ne može zamisliti bez primjene novih tehnologija.

\section{Bilješke}

/1/ Hilčenko S. (2008). Obrazovni softver kao podsticajno sredstvo u učenju rešavanjem problemsko-logičkih zadataka učenika razredne nastave, Učiteljski fakultet, Beograd Inovacija u nastavi, br. 3/08, str. 62-68

/2/ Hilčenko S. (2015). An E-model of a Flipped \& Heuristic and Functionally \& Logical Learning for the Generation "Z" In the Classwork, Sciencepublishing group, USA, International Journal of Elementary Education, Vol. 4, Issue Number 3, pp. 65-79

13/ C4LPT, Centre for Learning \& Perfomanse Tehnologies http://c4lpt.co.uk/ Preuzeto 07.01.2018.

/4/ Hilčenko S. (2016). Primena multimedije u oblasti podučavanja osnovnim matematičkim pojmovima u predškolskoj ustanovi, Učenje i nastava, "Klett" društvo za razvoj obrazovanja, godina II broj 3, str. 591-608, Beograd.

15/ Free Web Apps http://online-voice-recorder.com/ Preuzeto 18.01.2018.
/6/ GifMaker.Me http://gifmaker.me/__Preuzeto 22.02.2018.

17/ Online-Convert.com http://audio.onlineconvert.com/convert-to-wav Preuzeto 24.02.2018.

/8/ Clements D. H., Sarama J. (2003). "Young children and technology: What does the research say? Young Children", 58(6), pp. 34-40.

19/ Čičević S., Trifunović A., Živanović M. (2014). Primena interneta za testiranje prepoznavanja geometrijskih oblika predškolske dece, SINTEZA 2014 - međunarodna naučna konferencija Univerziteta Singidunum, Saobraćajni fakultet, Beograd, Zbornik radova, str. 407-411.

/10/ Hilčenko S. (2017). How generation "Z" learns better?, European Journal of Social Sciences Education and Research, Vol.11 Nr. 2, pp. 379-389.

/11/ Hilčenko S. (2014). Obrazovna tehnologija, udžbenik za studente, vaspitače i roditelje dece predškolskih ustanova, (prvo izdanje), Visoka škola strukovnih studija za obrazovanje vaspitača i trenera - Subotica, Subotica.

/12/ Nadić D. (2014). Održivi razvoj i principi održivog razvoja u strateškim dokumentima republike Srbije, str. 213-224. Rad je nastao u okviru naučnoistraživačkog projekta Univerziteta u Beogradu Fakulteta političkih nauka, Politički identitet Srbi je $\mathrm{u}$ regionalnom i globalnom kontekstu (evidencioni bro j: 179076), koji finansira Ministarstvo prosvete i nauke Republike Srbije.

/13/ Kisamore A. N., Carr J. E., Leblanc L. A. (2011). Training Preschool Children to use Visual Imagining as a Problem-Solving Strategy for Complex Categorization Tasks 


\title{
"WHAT IS ONE METER?" \\ RESULTS OF COMPARATIVE ANALYSIS OF TEST RESULTS TWO APPROACHES IN LEARNING OF THIS THEME IN KINDERGAR- TEN
}

\author{
Slavoljub Hilcenko ${ }^{1}$, Vukan Popović 2 \\ College of Vocational Studies for Teacher and Trainers Education, Subotica, Serbia ${ }^{1}$ \\ Elementary School "Isa Bajic", Kula, Serbia
}

Abstract

Students from the department of teachers and trainers at College of Vocational Studies in Subotica are developing e-didactical learning tools as a part of their exercises from the subject Application of computers in kindergartens, which find their practical application in preschool educational institutions on the territory of Subotica, Sombor, Vrbas and Kula municipalities. Such learning tools are very scarce, while available ones are in foreign language or do not satisfy the didactically-methodical aspects. On the other hand, according to the educators, they stagger from such approach towards work, if it is not simple and intuitive in use, and more effective and incentive for children than the traditional approach. The aim of the paper is the introduction of a single e-learning tool, i.e. comparative analysis of test results of both approaches on the same topic. Achieved experimental results are on the side of the group of preschool children from the Methodology of Mathematics, which used e-learning tools - multimedia-animated and interactive PowerPoint presentation "What is one meter?" on tablet computers in regard to traditional approach - activity of educator and examinations - classic (nonverbal, textually-applicative) test - worksheet with five tasks. Prior to the research, out of 400 interviewees which were verbally tested, $368(92.0 \%)$ children stated that they would prefer acquiring a new topic via e-learning tools, which confirms the degree of motivation that it implicitly / explicitly possesses.

Key words

E-learning tools, higher efficiency, motivation, meter, simple application 